\title{
Mordellidae (Coleoptera) Research: A Review Based on the Zoological Record from 1864 through 2013
}

\author{
Yang Liu ${ }^{1,2,3, *}$, Terry L. Erwin ${ }^{3}$ and Xingke Yang ${ }^{2, *}$ \\ 1 Key Laboratory of Resource Biology and Biotechnology in Western China (Northwest University), Ministry \\ of Education, College of Life Science, Northwest University, Taibai North Road 229, Xi'an 710069, China \\ 2 Key Laboratory of Zoological Systematics and Evolution, Institute of Zoology, Chinese Academy of Sciences, \\ Beijing 100101, China \\ 3 Department of Entomology, National Museum of Natural History, Smithsonian, \\ Washington, DC 20013, USA; erwint@si.edu \\ * Correspondence: liuyangent@nwu.edu.cn (Y.L.); yangxk@ioz.ac.cn (X.Y.)
}

Received: 25 July 2018; Accepted: 22 August 2018; Published: 3 September 2018

check for updates

\begin{abstract}
Mordellidae (tumbling flower beetles) is a globally distributed family of Coleoptera; it is among the most species-rich families (containing 115 genera and 2308 species described). It is important because of its agroforestry significance and its ecosystem-sustaining attributes. However, the past and current status of Mordellidae research remains unclear. A comprehensive literature review of Mordellidae articles published over the period of 1864-2013 based on the Zoological Record was conducted for the first time. A total of 863 articles were used for analysis after a strict literature search using screening protocols. These articles were then assigned to four categories based on the year of publication, topics/themes, primary authors, and frequently utilized journals for publication of Mordellidae-related articles. The results reveal that: (1) there are three prosperous research periods (1876-1898, 1922-1957, and 1977-2012) for Mordellidae during 1864-2013 that are associated with the active period of three generations of the main taxonomists. However, it is unfortunate that it also demonstrates there is a lack of upcoming researchers to continue the work after the retirement of the current generation, thus action should be taken immediately to promote research on Mordellidae; (2) on average, each primary author published 3.1 papers, but $\sim 35 \%$ of the Mordellidae articles were published by less than $3 \%$ of the primary authors; (3) researchers tended to mostly publish their articles in local journals of their home countries; (4) more than $90 \%$ of the articles pertain to traditional taxonomy, with those of early times generally containing only simple descriptions of the species and the holotypes chosen are sparsely deposited with the researchers or amateurs around the world, thus making them difficult to be checked; (5) nearly half of the studies described Mordellidae species from Palaearctic realm, about one-third of the studies described species in other areas rather than in the fauna in which the authors lived, and about two-fifths of the studies described species from countries outside of the authors' country of origin. Therefore, the in-depth systematic study of worldwide Mordellidae is required to reconstruct Mordellidae phylogeny and a revision of its classification system with modern methods of comparative morphology, molecular biology, zoogeography, and cladistics. In order to better understand the life stages and biology of Mordellidae insects, more work on Mordellidae ecology should be undertaken to develop strategies for pest control. We hope that this review will provide information to the novice and expert alike in Mordellidae research pertaining to its past and current status, possible future research areas, and attract more attention from the scientific world and renew an interest in Mordellidae research.
\end{abstract}

Keywords: Mordellidae; academic literature review; classification framework; Zoological Record; list of generic taxa with citation 


\section{Introduction}

The Mordellidae (also called tumbling flower beetles) is a family of beetles with a great number of species. More than 2308 Mordellidae species belonging to 115 genera have been recorded so far and more species are appearing in the literature often, including 45 new species in the past 10 years. Mordellidae are found worldwide in a variety of ecosystems, from tropical rainforests to arctic tundra, and from sea level to elevations of above $4000 \mathrm{~m}$ (>13,123 ft). Adult Mordellidae are found on dead or partly dead trees and a great many of them are pollinators [1,2]. While generally their larvae feed on the sap of vascular plants, some larvae are also found in dead trees, or still others bore in the pith of plants, hard mushrooms, and some are even predaceous on other larvae (e.g., lepidopterous and dipterous larvae) [1,3]; some of them are therefore important agricultural and forestry pests.

Linneaus is considered to be the Mordellidae pioneer who established Mordella, the first genus of Mordellidae, in 1758 [2]. However, it was not until 1802 that Mordellidae was actually established by Latreille [4], which marks the start of the traditional taxonomy of Mordellidae. It is should be noted that for a long period of time (until 1855), Ripiphoridae were considered a part of Mordellidae. However, current molecular studies provide weak support for this monophyly $[5,6]$, which is in contradiction with the morphology and biology of the groups [5,7]. A considerable amount of work has been done by investigators around the world since then. It is of paramount importance to collate and synthesize these previous studies in order to provide a general picture of historical Mordellidae research that will serve future research $[8,9]$. However, to our knowledge, no one has collated and synthesized these works. The objective of this study is therefore to understand the state of Mordellidae research by examining the published literature. Based on the Zoological Record, publications pertaining to Mordellidae from 1864 through 2013 were screened and analyzed to provide insights for Mordellidae practitioners and researchers alike on the major turning points of historical trends in and the implications for the future directions of Mordellidae research, as well as to compile a systematic reference to the Mordellidae literature.

Although many genera/species (e.g., Conalia (Mulsant \& Rey, 1858), Ctenidia (Laporte de Castelnau in Brullé, 1840), Curtimorda (Naezen, 1794), Hoshihananomia (Sulzer, 1776), Mordella (Linnaeus, 1758; Eichwald, 1830), Mordellistena (Linnaeus, 1758; Panzer, 1796; Fabricius, 1798; Gyllenhal, 1810, 1819, 1827), Mordellocbroa (Fabricius, 1775), Tolida (Mulsant, 1856), Tomoxia (Gyllenhal, 1827; Rossi, 1794), and Variimorda (Schrank, 1781; Comolli, 1837)) were described between 1758 and 1864 [4], pioneer research within this period is not included due to the following reasons: (1) there is a lack of literature and limited access to holotypes of the previously described species [2]; (2) insufficient descriptions (e.g., undescribed or rarely mentioned sexual divergences) given by previous researchers make it difficult to identify and classify this family [1]; and (3) many specimens were incorrectly identified and the system of taxonomic arrangement has been changed by later researchers $[1,4]$.

\section{Methods for the Literature Search}

The scope of this investigation was limited to the time frame 1864-2013 because publications in various journals of this period were recorded in the Zoological Record, a ready source of taxonomic literature with coverage back to 1864 (published annually by Thomson Reuters). Zoological Record can be used to determine the first appearance of an animal in the published literature, track the changes in classification, and monitor the developments in ecology, conservation, and wildlife management/preservation. The literature recorded by the Zoological Record also (1) mirrors the developments and evolution in techniques and methods for Mordellidae research and (2) reflects the renewal of researchers' interest in such research after the adoption of new techniques, as will be discussed in next section.

The literature search was based on the descriptor "Mordellidae" in the title, key words, and/or abstract in the Zoological Record. The full text or abstract of each article was reviewed to eliminate articles that were not related or when only a minor section was about Mordellidae. 


\section{Results and Discussion of the Analysis}

Our literature search and screening, performed according to the established procedures and criteria, returned 863 published papers in 300 different journals during the period 1864-2013. We categorized this literature in a few different ways, such as year of publication, journals, topics, authors and their affiliated countries, and geographic origin of described species, and these categories are analyzed and discussed accordingly below. This particular analysis should provide guidelines for the pursuit of future research on Mordellidae and its applications by explaining the chronological growth of Mordellidae over the years, the challenging areas of Mordellidae research, and the major issues surrounding taxonomy, ecology, pest control, and phylogeny.

\subsection{Distribution of Articles by Year of Publication}

The article distribution pattern by year of publication (from 1864 through 2013) is illustrated in Figure 1. It shows a growing trend in the research on Mordellidae over this period and is marked by three high-volume periods: (1) 1876-1898; (2) 1922-1957; and (3) 1977-2012. Fluctuations of publications during these three periods are observed in each period and the greatest number of articles is found in 1999 (21). These three high-volume periods are associated with the active period of some of the main taxonomists, or three generations of Mordellidae researchers. For example, the active period of Pic, M. (1899-1954), Champion, G.C. (1890-1927), and Fairmaire, L. (1891-1906), who were the main contributors for the first high-volume period, as shown in Figure 1. Ermisch, K. (1940-1972) and Franciscolo, M. (1942-2001) contributed to the second high-volume period. Horak, J. (1978-2012), Takakuwa, M. (1976-2010), and Odnosum, V.K. (1983-2003) made the third high-volume period.

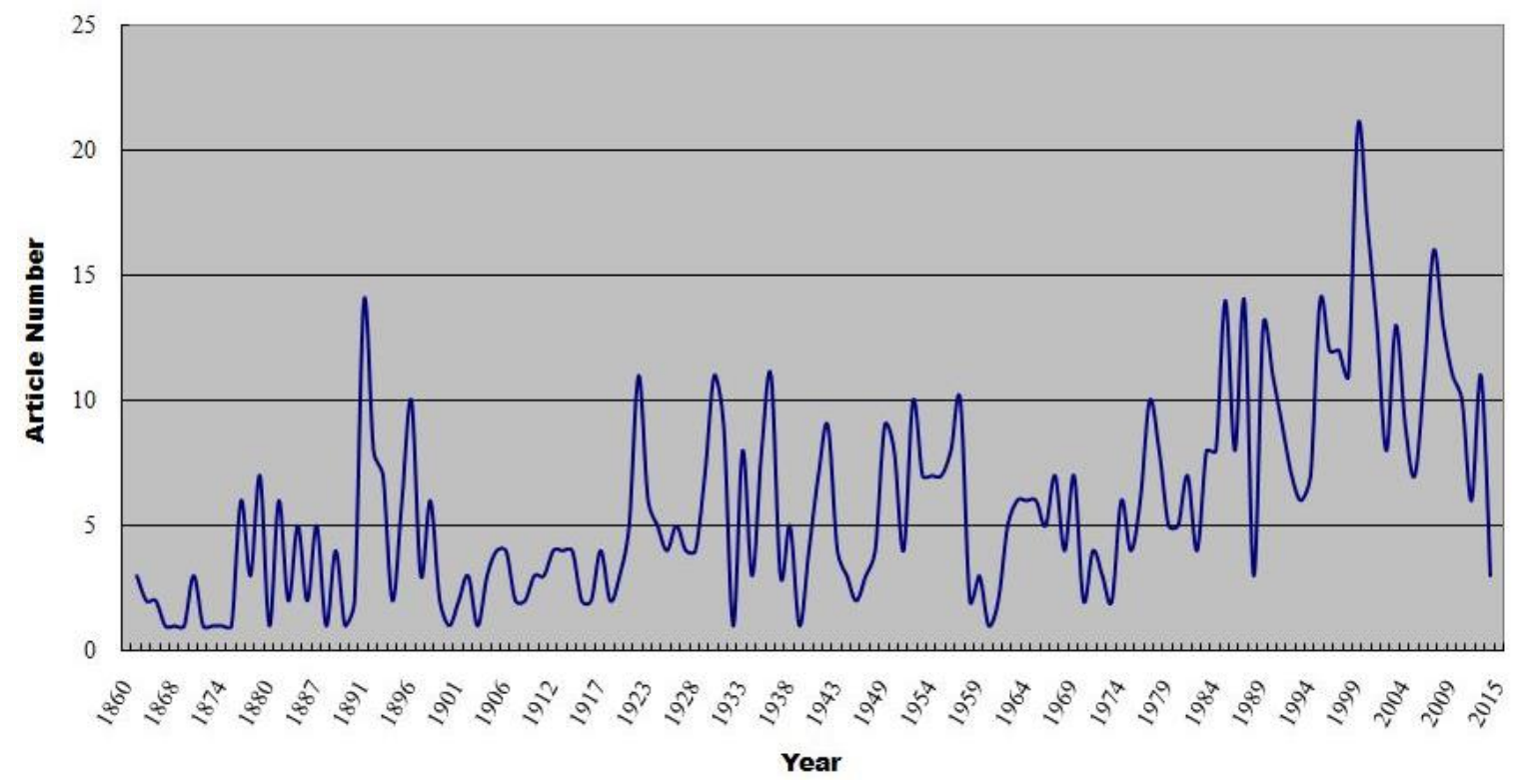

Figure 1. Annual number of articles on Mordellidae over the period from 1864 through 2013.

The number of articles grew more quickly than ever since the early 1980s through 2013, after which the number of Mordellidae articles fell precipitously, which could be attributed to the retirement of nearly all of the most prolific tumbling flower beetle taxonomists, mainly in European countries. Unfortunately, these eminent researchers have not been replaced by a new generation of Mordellidae experts [2]. The situation of Mordellidae research is much different from other fields such as leafhoppers, which has had a large group of young taxonomists in recent years [8]. 


\subsection{Distribution of Articles by Journal}

The number of journals under the category of insect sciences has been increasing considerably, from 87 journals in 2000 to 127 journals in 2010 and 143 journals in 2017 (accessed on 11 August 2018). However, only a portion of the journals have been utilized by Mordellidae researchers. Table 1 illustrates the distribution of Mordellidae articles by journal. It should be noted that there are 43 journals that published over 10 Mordellidae papers, mostly on topics of taxonomy. Vestnik Zoologii published 54 Mordellidae related articles in total, followed by Bulletin de la Societe Entomologique de France with 52 articles, and then Elytra with 50 articles. It is interesting to notice that the authors of these articles are mainly from countries where the journals were established, as will be discussed below. In these more utilized journals, a great number of previous works were dedicated to classification. Considering the changes in the recent trend in the publication of Mordellidae articles, a brief introduction to some of the most utilized journals is given below for the reader's reference.

Table 1. The distribution of articles by journals.

\begin{tabular}{|c|c|}
\hline Journals & Article Number \\
\hline Vestnik Zoologii & 54 \\
\hline Bulletin de la Societe Entomologique de France & 52 \\
\hline Elytra & 50 \\
\hline Entomologist's Monthly Magazine & 46 \\
\hline Entomological Review of Japan & 34 \\
\hline L'Echange, Revue Linnéenne & 28 \\
\hline Acta Entomologica Bohemoslovaca & 26 \\
\hline Canadian Entomologist & 26 \\
\hline Deutsche Entomologische Zeitschrift & 26 \\
\hline Entomologische Blaetter Krefeld & 26 \\
\hline Reichenbachia & 26 \\
\hline Bollettino della Societa Entomologica Italiana & 24 \\
\hline Entomologische Blaetter fuer Biologie und Systematik der Kaefer & 24 \\
\hline Melanges Exotico-Entomologiques Moulins & 24 \\
\hline Transactions of the Entomological Society of London & 24 \\
\hline Notulae Entomologicae & 22 \\
\hline Coleopterists' News & 20 \\
\hline Annales de la Societe Entomologique de France & 18 \\
\hline Coleopterists Bulletin & 18 \\
\hline Entomologische Berichten & 18 \\
\hline Entomologist's Record and Journal of Variation & 18 \\
\hline Proceedings of the Linnean Society of New South Wales & 18 \\
\hline Annales de la Societe Entomologique de Belgique & 15 \\
\hline Acta Societatis Zoologicae Bohemicae & 14 \\
\hline Berliner Entomologische Zeitschrift & 14 \\
\hline Memorie della Societa Entomologica Italiana & 14 \\
\hline Annali del Museo Civico di Storia Naturale "Giacomo Doria" & 12 \\
\hline Annals \& Magazine of Natural History & 12 \\
\hline Bulletin of the Osaka Museum of Natural History & 12 \\
\hline Coleopterist & 12 \\
\hline Environmental Entomology & 12 \\
\hline Insecta Matsumurana Sapporo & 12 \\
\hline Kaefer Europas & 12 \\
\hline Pan-Pacific Entomologist & 12 \\
\hline Proceedings of the Royal Entomological Society of London & 12 \\
\hline Special Bulletin of the Japanese Society of Coleopterology & 12 \\
\hline Studies and Reports of District Museum Prague-East Taxonomical Series & 12 \\
\hline Transactions of the Royal Society of South Australia & 12 \\
\hline Annals of Natural History & 10 \\
\hline Arkiv for Zoologi Stockholm & 10 \\
\hline Bulletin of the Brooklyn Entomological Society & 10 \\
\hline Ecological Entomology & 10 \\
\hline Revue Francaise d'Entomologie & 10 \\
\hline Total & 863 \\
\hline
\end{tabular}


Vestnik Zoologii (Zoological Herald) is a bimonthly journal founded in 1967 in Ukraine; it publishes original papers in all fields of zoology. We found that all of the 54 Mordellidae articles published in this journal are from V.K. Odnosum (1983-2009), who is also a Ukrainian.

Bulletin de la Societe Entomologique de France was officially founded in 1832 with the sponsorship of the Entomological Society of France, which is the oldest entomological society in the world. There are 52 Mordellidae articles published over the period from 1868 to 2001 . The main taxonomists are A. Chobaut (first and last year of publication on this journal: 1894-1924, six articles) and M. Pic (1899-1942, eight articles).

Elytra is the third top journal that has published Mordellidae articles. This journal was established in 1973 and is sponsored by the Coleopterological Society of Japan; it has published 50 articles about Mordellidae until now. M. Takakuwa (1976-2010, 19 articles) and T. Tsuru (2004-2012, 5 articles, including 3 articles that are coauthored with M. Takakuwa) are the main researchers. Coleopterists' News (1968-2010, in Japanese) is the other journal sponsored by the Coleopterological Society of Japan; it has published 11 Mordellidae articles. All the Mordellidae articles published in this journal from 1998 to 2007 are by M. Takakuwa.

The Entomologist's Monthly Magazine is a British entomological journal that started publication in 1864. The journal publishes original papers and notes on all orders of insects and terrestrial arthropods from around the world, specializing in groups other than Lepidoptera. There are 46 articles published in this journal, with the main contributor being G.C. Champion (1891-1927, 11 articles) and K.G. Blair (1922-1934, 5 articles).

\subsection{Distribution of Articles by Topic}

Articles are divided into five categories based on the topics/theme, including traditional taxonomy, molecular, bioinformatics, ecology, and pest control. Each category is discussed separately and some good examples are given below:

(1) Traditional taxonomy classifies Mordellidae according to their morphological attributes. More than $90 \%$ of these articles were found to be traditional morphology based, with simple descriptions of new species only. The preponderance of taxonomists at the beginning of 18th century was European; after that, researchers from Asia and America started working on them. Some milestone research works worth attention over the traditional taxonomy period are: (1) Khalaf [10] and Odnosum [11], who discussed wing venation of Mordellidae and found phylogenetic relationships in Mordellidae by the structure of hindwings; (2) Lu et al. [12] compared male genitalia of 12 different genera and found phylogenetic relationships in North American Mordellidae; (3) Odnosum [13-17], who discussed several morphological characteristics of Mordellinae, including antennae, mouthparts, sternum, structure of wings, male genitalia, etc. Instead of describing only the maxillary palp of males, as did most researchers, Odnosum [18,19] described other morphological characteristics of both male and female Mordellidae. There are also important studies of M. Franciscolo and many others which are not mentioned above.

(2) Ecologists investigate the life history of Mordellidae species and their biology (e.g., plants, water, temperature, natural hazards, and other insects). Life history is critical to the study of disease transmission. Hayashi [20] showed that larvae of some genera of Mordellidae live in dead trees in Japan. Mamayev and Odnosum [21] presented new data on morphology and systematics of five species of Mordellidae larvae of Far Eastern USSR fauna. Ford and Jackman [22] connected 11 species of Mordellidae and 22 species of hosts and reported new larval host plant associations in North America. Zemoglyadchuk [23] reported the morphological attributes of larvae of three species of Mordellistena parvula groups and stressed the importance of studying larval hosts to identify species of Mordellidae. Identification of larval hosts may also facilitate understanding the life cycle of Mordellidae species and the development of pest control strategies.

(3) Pest control. Mordellidae are of significant agroforestry importance, e.g., many species are pollinators, while some species are pests that lead to great economic losses. Therefore, better 
understanding of the classification and ecology of Mordellidae can facilitate the development of strategies for pest control. Unfortunately, few articles found in the Zoological Record reported the threats and prevention of Mordellidae. The few available reports are about their risk to sunflowers. Fan [24] stated the reason for the investigation and recording of new species of Mordellidae was that Mordellidae are harmful to the local sunflower industry in China. Qureshi et al. [25] reported that plant populations and weeds influence stalk insects (Mordellidae), soil moisture, and yield in rain-fed sunflowers.

(4) Fossil studies. Fossil Mordellidae are rarely found and reported [26], but they can be valuable to understanding the evolutionary history of Mordellidae. The earliest Mordellidae fossils found in the Karatau Range in Kazakhstan were considered to be from the Late Jurassic; it was described as a new genus and species, Praemordella martynovi Scegoleva-Barovskaja [27]. Based on this, Scegoleva-Barovskaja [27] defined a new subfamily Praemordellinae under the family Mordellidae. Medvedev [28] established a new genus (Scraptiomima) based on the recovered fossils in the Transbaykalia region of USSR. In 1993, Wang [29] established the monotypic family Liaoximordellidae based on a fossil from Liaoning, China. This family is now regarded as a fossil genus, Liaoximordella of the Mordellidae. In addition, Jell and Duncan [30] also reported Mordellidae fossils in Victoria, Australia. Huang and Yang [26] established a new genus (Cretansapis) based on fossils recovered at Fangshan, Beijing, China and discussed the evolution and taxonomic position of Mordellidae. Cockerell [31] reported a few fossil insects deposited at the United States National Museum, in which there was a new species of Mordellidae, Mordella priscula Cockerell 1925. Other researchers, such as Statz [32], Nel [33], Kubisz [34], Liu et al. [35,36], Peris and Ruzzier [37], and Odnosum [38], also reported new fossil/amber Mordellidae species, or established a new genus based on the described species.

\subsection{Distribution of Articles by Author}

There are 268 primary authors for the 863 articles, which is $\sim 3.2$ papers on average for each author over the last 150 years (1864-2013). Over half of the 863 papers were published by researchers who published 10 or more Mordellidae articles. As Figure 2 shows, the top contributors are: M. Pic (48 articles, the period of his related research from 1899 to 1954), K. Ermisch (58 articles, the period from 1940 to 1972), M. Franciscolo (57 articles, 1942-2001), J. Horak (41 articles, 1978-2012), M. Takakuwa (38 articles, 1976-2010), V.K. Odnosum (33 articles, 1983-2009), and G.C. Champion (23 articles, 1890-1927). These seven researchers ( $3 \%$ of the 268 primary authors) published over one-third of the total articles (298), which may indicate that Mordellidae may be the expertise or focus of a very small portion of these authors. A summary of articles for the significant contributors is shown in Table 2.

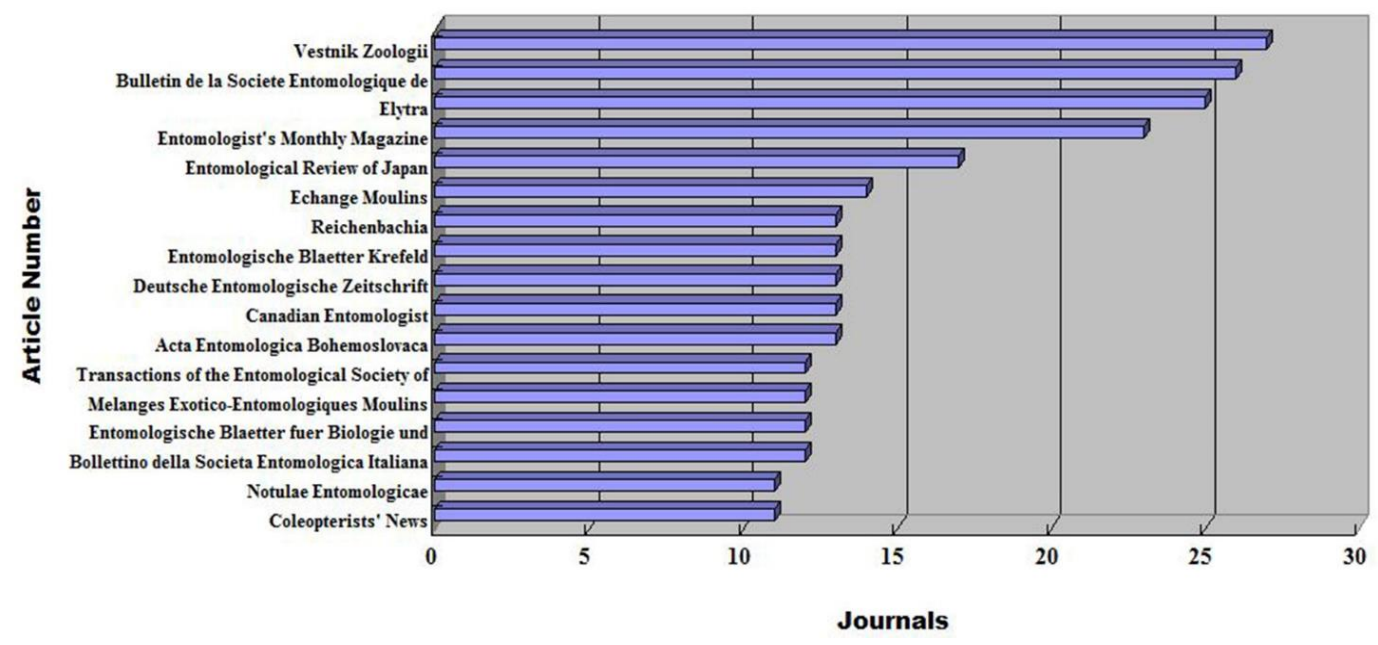

Figure 2. The distribution of articles by journal. 
Table 2. The distribution of articles by primary authors, years, and countries.

\begin{tabular}{cccc}
\hline Name & Period & Article Number & Country \\
\hline Pic, M. & $1899-1954$ & 64 & France \\
Ermisch, K. & $1940-1972$ & 58 & Germany \\
Franciscolo, M. & $1942-2001$ & 57 & Italy \\
Horak, J. & $1978-2012$ & 41 & Czech \\
Takakuwa, M. & $1976-2010$ & 38 & Japan \\
Odnosum, V.K. & $1983-2009$ & 33 & Ukraine \\
Champin, G.C. & $1890-1927$ & 23 & Britain \\
Fairmaire, L. & $1891-1906$ & 18 & France \\
Batten, R. & $1976-1990$ & 15 & The Netherlands \\
Ray, E. & $1930-1947$ & 15 & USA \\
Blair, K.G. & $1915-1942$ & 13 & Britain \\
Nomura, S. & $1957-1967$ & 11 & Japan \\
Lea, A.M. & $1895-1931$ & 11 & Australia \\
Nakane, T. & $1949-1960$ & 10 & Japan \\
Kolbe, H. & $1910-1934$ & 10 & German \\
Chobaut, A. & $1892-1924$ & 10 & France \\
Kangas, E. & $1976-1988$ & 9 & Finland \\
Schilsky, J. & $1895-1910$ & 9 & Germany \\
Tsuru, T. & $2002-2012$ & 8 & Japan \\
Shiyake, S. & $1994-2001$ & 8 & Japan \\
Allen, A.A. & $1975-2007$ & 8 & Britain \\
Chujo, M. & $1935-1964$ & 8 & Japan \\
Roubal, J. & $1921-1935$ & 7 & German \\
Kiyoyama, Y. & $1875-2010$ & 7 & Japan \\
Lu, W. & $1997-2009$ & 6 & America \\
Kubisz, D. & $2000-2010$ & 5 & Poland \\
Liljeblad, E. & $1917-1945$ & 5 & USA \\
Wickham, H.F. & $1909-1914$ & 5 & Australia \\
Xambeu, V. & $1893-1908$ & 5 & \\
Blackburn, T. & $1891-1893$ & 5 & \\
\hline & & & \\
\hline
\end{tabular}

We also investigated the country origins of the primary authors (Table 2). The results showed that Mordellidae research is heavily internationalized, with the majority of authors from European and Asian countries.

\subsection{Distribution of Geographic Origin of Described Species}

We investigated the distribution of the geographic origin of described species by animal fauna (i.e., Palearctic realm, Nearctic realm, Neotropical realm, Ethiopian realm, Oriental realm, and Australian realm). There are 401 Mordellidae studies related to species in the Palearctic realm, 114 in the Oriental realm, 90 in the Ethiopian realm, 88 in the Nearctic realm, 59 in the Australian realm, and 49 in the Neotropical realm. Twenty-two studies described species from two realms, two publications described species from more than two realms, and the rest focused on species from a single realm. It is interesting to note that more than 250 studies described species from other animal fauna rather than the fauna from the region to which the authors belonged. This might be evidence of increased international collaboration or lack of described species from authors' own realms. By comparing the country of origin for the described species and authors, we found that more than 350 studies described species from countries outside of the authors' country of origin.

\section{Conclusions and Future Studies}

Mordellidae is among the most important families of Coleoptera, with 115 genera and 2308 species distributed worldwide. These taxa play critical roles in the function and sustainability of the ecosystem. The larvae of some species are important pests for agricultural and forestry industries, while at the 
same time the adults are beneficial pollinators. In order to obtain a general picture of global mordellid research, we undertook a comprehensive review of articles on the family covering the period from 1864 through 2013 based on the Zoological Record. To the best of our knowledge, this is the first academic literature review on Mordellidae research depicting the past and current status of the family [2].

A total of 863 articles were selected for analysis following strict literature search and screening protocols. These articles were then divided into four categories based on the year of publication, journals, topics/themes, and primary authors. Our results demonstrate the following:

(1) In these 863 papers, traditional taxonomy is the dominant topic, accounting for more than $90 \%$ of the total articles. In addition, literature of earlier times generally contains only simple descriptions of the species, with these being less likely to be used for phylogenetic classification. The holotypes used were non-discretely deposited around the world, making future research more difficult.

(2) There are 268 primary authors for the 863 articles, with $\sim 3.1$ papers on average for each author over the last 150 years (1864-2013). It is interesting to note that $36 \%$ of the Mordellidae articles were published by only $3 \%$ of the primary authors, which may indicate that only a few researchers have focused on this family and the rest of them did not attempt to conduct in-depth and systematic studies of Mordellidae. The underlying reason for this remains unknown.

(3) Mordellidae research had three high-volume periods, and these were associated with the active periods of some of the main taxonomists, i.e., three generations of Mordellidae researchers.

(4) We found the distribution of articles by journal to be very interesting. Early publications were made by authors mainly from countries where the journals were established. Later, there has been an increasing trend toward publishing in international journals.

(5) The Palearctic realm is the most frequently studied region for Mordellidae, accounting for about half of the studies, while about one-third of the studies described species from other animal fauna rather than the fauna from the region to which the authors belonged. Similarly, we found that $40 \%$ of the studies described species from countries outside of the authors' country of origin.

Our conclusions based on the literature analysis are that many genera and species need to be revised, especially old Mordellidae descriptions. Further, new species need to be described, especially those in less studied regions, such as the Oriental realm, the Ethiopian realm, the Nearctic realm, the Australian realm, and the Neotropical realm. Along with these revisions and new descriptions, there is a need for an in-depth systematic study of worldwide Mordellidae, which is of paramount importance for modern phylogenetic reconstruction and an overhaul of the family's classification system. Using modern methods of comparative morphology, molecular biology, zoogeography, and cladistics will secure a better understanding of the world's Mordellidae fauna. A list of the Mordellidae generic taxa can be found in the Appendix A.

Furthermore, the employment of molecular techniques has been proven to significantly improve the accuracy of taxonomy of many other families of Insecta [39]. Thus, phylogenetic studies based on both morphological and molecular data should be the main direction for future studies, especially at the species level, where distinct morphological characteristics are difficult to identify. Additionally, attention should also go to the study of Mordellidae's way of life, so as to better understand the life stages of tumbling flower beetles and their relationships to environments; this can also serve as the foundation for developing strategies for pest control.

However, as our literature review amply demonstrates, the retirement of the third generation of eminent Mordellidae researchers has unfortunately left a research vacuum, as nearly no one is taking over their research tasks. In addition, there are no large-scale funds or training programs for taxonomists in Mordellidae and the lack of taxonomists and funds have also been reported in other research in Insecta and biodiversity [40-44]. We therefore believe actions should be undertaken immediately to promote the research of Mordellidae and attract more attention from the scientific world. We hope that this lengthy literature review and analysis of the field of Mordellidae research will be the beginning of a resurgence. 
Author Contributions: Y.L., T.L.E., and X.Y. wrote and commented on the manuscript.

Funding: This research was funded by the National Natural Science Foundation of China grant number (31401998), China Postdoctoral Science Foundation grant number 2013M541038, National Science Foundation for Fostering Talents in Basic Research of the National Natural Science Foundation of China grant number J1210063, and West Light Foundation of the Chinese Academy of Sciences to Yang Liu.

Acknowledgments: We would like to thank Yaling Zhao for assistance in the data processing and editing the List of Mordellidae Generic Taxa.

Conflicts of Interest: The authors declare no conflicts of interest.

\section{Appendix A}

Table A1. List of Mordellidae Generic Taxa.

\begin{tabular}{|c|c|c|c|c|c|}
\hline Family & Subfamily & Tribe & Genus & Sugenus & Citation \\
\hline \multirow{9}{*}{ Mordellidae } & & & & & $\begin{array}{l}\text { Latreille, 1802 } \\
\text { (Seidlitz, 1875) } \\
\text { Franciscolo, 1942 } \\
\text { Crowson, 1953 } \\
\text { Franciscolo, 1956: } 2 \\
\text { Franciscolo, 1962: } 98 \\
\text { Serrahima Ignasi, 2007: } 560\end{array}$ \\
\hline & \multirow[b]{2}{*}{ Ctenidiinae } & & & & Franciscolo, 1951a: 56 \\
\hline & & & Ctenidia & & $\begin{array}{l}\text { Laporte de Castelnau in Brullé, } 1840 \\
\text { Franciscolo, 1951a: } 56\end{array}$ \\
\hline & \multirow{6}{*}{ Mordellinae } & & & & 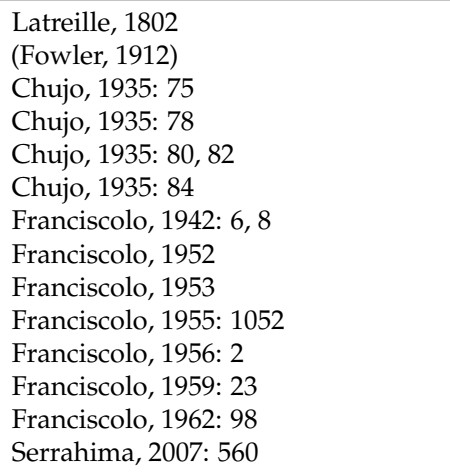 \\
\hline & & \multirow{5}{*}{ Conaliini } & & & $\begin{array}{l}\text { Ermisch, } 1956 \\
\text { Lu, 1997: } 756\end{array}$ \\
\hline & & & Conalia & & $\begin{array}{l}\text { Mulsant \& Rey, 1858: } 313 \\
\text { Champion, 1896: } 49 \\
\text { Champion, 1898: } 98 \\
\text { Ray, 1941: 285 } \\
\text { Liljeblad, 1945: } 16 \text { [Hungary; Czech: } \\
\text { Moravia; North America; Europe] } \\
\text { Ermisch, 1950: } 73 \\
\text { Ermisch, 1956: } 304 \\
\text { Downie, 1996: } 1155 \text { [North-Eastern } \\
\text { America] } \\
\text { Lu, 1997: } 756\end{array}$ \\
\hline & & & Conaliamorpha & & Ermisch, 1968c: 225 \\
\hline & & & Glipodes & & $\begin{array}{l}\text { LeConte, 1862: } 47-48 \\
\text { Emery, 1876: 79 } \\
\text { Smith, 1882: 74, } 84 \text { [America] } \\
\text { Champion, 1891: } 305 \\
\text { Blatehley, 1910: 1309, } 1315 \\
\text { Ray, 1941: 285 [Mexico] } \\
\text { Liljeblad, 1945: 14 [North America] } \\
\text { Ermisch, 1950:72 } \\
\text { Downie \& Arnett, 1996: } 1155 \\
\text { [North-eastern America] }\end{array}$ \\
\hline & & & Isotrilophus & & Liljeblad, 1945: 18 [North America] \\
\hline
\end{tabular}


Table A1. Cont.

\begin{tabular}{|c|c|c|c|c|c|}
\hline Family & Subfamily & Tribe & Genus & Sugenus & Citation \\
\hline & & & Jakliella & & $\begin{array}{l}\text { Horak, 2010: } 558 \text { [Indonesia: West } \\
\text { Papua] }\end{array}$ \\
\hline & & & Javamorda & & Ermisch, 1968: 33-34 \\
\hline & & & Jenisia & & Horak, 2008: 78-79 [Madagascar] \\
\hline & & & Larisia & & $\begin{array}{l}\text { Emery, 1876: } 13 \\
\text { Liljeblad, 1945: } 220\end{array}$ \\
\hline & & & Lubosiella & & Horak, 2007: 60 [Vietnam] \\
\hline & & & Lycidomorda & & Horak, 2007: 66 [Philippines] \\
\hline & & & Mehlia & & $\begin{array}{l}\text { Horak, 2010: } 549 \text { [Malaysia: Malayan } \\
\text { Peninsula: Perak; Sabah; Indonesia: } \\
\text { Kalimantan, Sumatra, Ambon, Seram } \\
\text { Island, Tanimbar Archipelago: } \\
\text { Yamdena] }\end{array}$ \\
\hline & & & Mordellista & & French, 1933: 33-35 \\
\hline & & & Nassipa & & $\begin{array}{l}\text { Emery, 1876: } 13 \\
\text { Liljeblad, 1945: } 222\end{array}$ \\
\hline & & & Nipponanaspis & & Chujo, 1957: 11 \\
\hline & & & & Konaspis & Chujo, 1957: 14-16 \\
\hline & & & Ophthalmoconalia & & Ermisch, 1968: 268 \\
\hline & & & Palmorda & & Ermisch, 1969: 312 \\
\hline & & & Paraconalia & & Ermisch, 1968c: 237 \\
\hline & & & Paramordellistena & & Ermisch, 1950: 73 \\
\hline & & & Pelccotomoides & & Sharp \& Muir, 1912: 555 \\
\hline & & & Pseudoconalia & & Ermisch, 1950: 72 \\
\hline & & & Pseudomordella & & $\begin{array}{l}\text { Ermisch, 1950: } 73 \text { [Indonesia: } \\
\text { Sumatra] }\end{array}$ \\
\hline & & & Pseudomordellina & & Nakane, 1957: 49-50 \\
\hline & & & Pseudomordellisteno & & Ermisch, 1950: 24 \\
\hline & & & 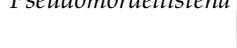 & Mordellina & Ermisch, 1952: 56 \\
\hline & & & Pulchrimorda & & $\begin{array}{l}\text { Ermisch, 1968 } \\
\text { Horak, 2007: } 69 \text { [China; Indonesia; } \\
\text { Philippines] }\end{array}$ \\
\hline & & & Rhipiphorus & & Quedenfeldt, 1886: 128 \\
\hline & & & Scaphiostena & & Horak, 1994: 191 \\
\hline & & & Scraptia & & Xambeu, 1908: 284 \\
\hline & & & Silaria & & $\begin{array}{l}\text { Mulsant, 1856: 39, } 426 \\
\text { Liljeblad, 1945: } 219\end{array}$ \\
\hline & & & Sinopalpus & & Horak, 2007: 78 [China] \\
\hline & & & Sphingoccphalus & & Liljeblad, 1945: 206 \\
\hline & & & Stenoconalia & & Ermisch, 1967: 130 \\
\hline & & & Striganaspella & & Ermisch, 1952: 100 \\
\hline & & & Striganaspis & & Ermisch, 1950: 87 \\
\hline & & & Xanthoconalia & & $\begin{array}{l}\text { Franciscolo, 1942 } \\
\text { Franciscolo, 1943: } 292 \text { [Congo] } \\
\text { Ermisch, 1950: } 73\end{array}$ \\
\hline & & & & & $\begin{array}{l}\text { Siedlitz, 1875 } \\
\text { Leconte \& Horn, 1883: } 408 \\
\text { Ermisch, 1941 } \\
\text { Ermisch, 1942 } \\
\text { Franciscolo, 1955: 1052 } \\
\text { Franciscolo, 1956: } 2 \\
\text { Franciscolo, 1959: } 23 \\
\text { Franciscolo, 1962: } 98 \\
\text { Nomura, 1967: 5 } \\
\text { Lu, 1997: 743 }\end{array}$ \\
\hline
\end{tabular}


Table A1. Cont.

\begin{tabular}{|c|c|c|c|c|c|}
\hline Family & Subfamily & Tribe & Genus & Sugenus & Citation \\
\hline & & & & & $\begin{array}{l}\text { Serrahima, 2007: } 560 \\
\text { Horak, 2009: } 207\end{array}$ \\
\hline & & & Adelptes & & Franciscolo, 1965 \\
\hline & & & Asiamordella & & Hong, 2002: 126 \\
\hline & & & Austromordella & & Ermisch, 1950: 63 \\
\hline & & & Binaghia & & Franciscolo, 1943: 1297 \\
\hline & & & Boatia & & Franciscolo, 1985: 79 [Ecuador] \\
\hline & & & Caffromorda & & $\begin{array}{l}\text { Franciscolo, 1943: 297, } 298 \\
\text { Ermisch, 1950: 56 } \\
\text { Franciscolo, 1952: } 66\end{array}$ \\
\hline & & & Calycina & & $\begin{array}{l}\text { Blair, 1922: } 222 \\
\text { Blair, 1934: } 250 \\
\text { Ermisch, 1950: } 71\end{array}$ \\
\hline & & & & Calycellina & Pic, 1932: 30 \\
\hline & & & Cephaloglipa & & $\begin{array}{l}\text { Franciscolo, 1952: } 350 \text { [New Guinea } \\
\text { Island] }\end{array}$ \\
\hline & & & Congomorda & & $\begin{array}{l}\text { Emery, 1876: 8, } 10 \\
\text { Ermisch, 1950: } 89 \\
\text { Ermisch, 1955: } 26 \text { [Congo] }\end{array}$ \\
\hline & & & Cothurus & & $\begin{array}{l}\text { Franciscolo, 1987: } 225 \\
\text { Champion, 1891: } 259 \\
\text { Champion, 1898: } 85 \\
\text { Ermisch, 1950: } 48\end{array}$ \\
\hline & & & Cretanaspis & & Huang \& Yang, 1999: 125 \\
\hline & & & Curtimorda & & $\begin{array}{l}\text { Méquignon, 1946: } 58 \\
\text { Ermisch, 1950: } 69 \\
\text { Tokeji, 1954: } 3 \\
\text { Ermisch, 1956: } 303\end{array}$ \\
\hline & & & Dollmania & & $\begin{array}{l}\text { Leconte, 1862: } 43 \\
\text { Tams, 1930: 174 } \\
\text { Ermisch, 1950: } 88 \\
\text { Franciscolo, 1961: } 15 \\
\text { Franciscolo, 1962: } 98\end{array}$ \\
\hline & & & Glipa & & $\begin{array}{l}\text { LeConte, 1859: } 17 \\
\text { Leconte, 1862: } 46 \\
\text { Smith, 1882: 79 } \\
\text { Champion, 1891: } 236 \\
\text { Champion, 1898: } 84 \\
\text { Chujo, 1935: 76 } \\
\text { Ermisch, 1940: 161-173 } \\
\text { Ermisch, 1941: 45 } \\
\text { Korschefsky, 1942: } 65 \\
\text { Liljeblad, 1945: } 20 \text { [America] } \\
\text { Ermisch, 1950: 66 } \\
\text { Franciscolo 1952: 55, } 57 \\
\text { Ermisch, 1965: 197 } \\
\text { Takakuwa, 1976: 16 } \\
\text { Takakuwa, 1977: } 9 \\
\text { Takakuwa, 1977: } 5 \\
\text { Takakuwa, 1986: } 260 \\
\text { Takakuwa, 1986: } 261 \\
\text { Downie \& Arnett, 1996: } 1155 \\
\text { [North-Eastern America; } \\
\text { North-Eastern Mexico] } \\
\text { Lu, 1997: 754 } \\
\text { Takakuwa, 2000: } 1 \\
\text { Takakuwa, 2002: } 357\end{array}$ \\
\hline & & & & Macroglipa & Nakane, 1960: 17 \\
\hline & & & & Stenoglipa & Nomura, 1967: 7 \\
\hline
\end{tabular}


Table A1. Cont.

\begin{tabular}{|c|c|c|c|c|c|}
\hline Family & Subfamily & Tribe & Genus & Sugenus & Citation \\
\hline & & & Glipidiomorpha & & $\begin{array}{l}\text { Franciscolo, 1952: } 347 \text { [New Guinea } \\
\text { Island] } \\
\text { Franciscolo, 1955: } 177\end{array}$ \\
\hline & & & Higehananomia & & $\begin{array}{l}\text { Kono, 1928: } 30 \\
\text { Kono, 1935: } 123 \\
\text { Ermisch, 1950:70 }\end{array}$ \\
\hline & & & Hoshihananomia & & $\begin{array}{l}\text { Kônô, 1935: 124 } \\
\text { Mequignon, 1946: } 56 \\
\text { Ermisch, 1950: } 65 \\
\text { Tokeji, 1954: } 3 \\
\text { Franciscolo, 1955: } 170 \\
\text { Ermisch, 1956: } 302 \\
\text { Lu, 1997: } 752\end{array}$ \\
\hline & & & Iberomorda & & Méquignon, 1946: 59 [Europe] \\
\hline & & & Ideorhipistena & & Franciscolo, 2000: 395 \\
\hline & & & Klapperichimorda & & Ermisch, 1968: 279 \\
\hline & & & Larinomorda & & Ermisch, 1968: 263 \\
\hline & & & Liaoximordella & & Wang, 1993: 87 \\
\hline & & & Machairophora & & Franciscolo, 1943: 34 \\
\hline & & & Macrotomoxia & & $\begin{array}{l}\text { Píc, 1922: } 208 \\
\text { Chujo, 1935: } 75 \\
\text { Ermisch, 1950: } 51 \text { [Laos; Japan: } \\
\text { Tokyo] }\end{array}$ \\
\hline & & & Mediimorda & & $\begin{array}{l}\text { Mequignon, } 1946 \\
\text { Ermisch, 1956: } 304 \\
\text { Leblanc \& Pascal, 2007: 235-250 }\end{array}$ \\
\hline & & & Mirimordella & & Liu, Lu \& Ren, 2007 \\
\hline & & & Mordella & & $\begin{array}{l}\text { Linnaeus, 1758: } 420 \\
\text { Tokeji, 1854: } 4 \\
\text { Chambers, 1881: 173-175 } \\
\text { Broun, 1880: 413 [New Zealand] } \\
\text { Linnaeus, 1882: } 80 \text { [America] } \\
\text { Smith, 1883 [Columbia] } \\
\text { Champion, 1891: 273-304 [Central } \\
\text { America] } \\
\text { Champion, 1891: 122-124 [Europe] } \\
\text { Champion, 1895: 266 [Western } \\
\text { Australia, Tasmania Island] } \\
\text { Champion, 1896: } 48 \\
\text { Kolbe, 1897: 254 } \\
\text { Champion, 1898: } 85 \\
\text { Xambeu, 1908:249 } \\
\text { Wickham, 1909: 130 } \\
\text { Nicolay, 1914: 30 } \\
\text { Champion, 1917: 178 [Seychelles] } \\
\text { Kono, 1928: 34 [Japan] } \\
\text { Scegoleva-Barovskaja, 1931: } 418 \\
\text { Chujo, 1935: 80 } \\
\text { Chujo, 1935: 78 } \\
\text { Liljeblad, 1945: } 30 \\
\text { Mequignon, 1946: } 59 \text { [Europe] } \\
\text { Normand, 1949: } 82 \\
\text { Ray, 1949: 278 [Fiji] } \\
\text { Buck, 1954: 16 } \\
\text { Ermisch, 1956: } 300 \\
\text { Franciscolo, 1956: } 2 \\
\text { Horak, 1979: 106 } \\
\text { Plaza, 1981: 198 } \\
\text { Downie, 1996: 1158 [Northeast } \\
\text { America; Northeast Mexico] } \\
\text { Lu, 1997: 750 } \\
\text { Serrahima \& Leblanc, 2007: 560 }\end{array}$ \\
\hline
\end{tabular}


Table A1. Cont.

\begin{tabular}{|c|c|c|c|c|c|}
\hline Family & Subfamily & Tribe & Genus & Sugenus & Citation \\
\hline & & & & Mediimorda & Mequignon, 1946: 62 \\
\hline & & & & Mordella & Mequignon, 1946: 60 \\
\hline & & & & Mordellistena & De Bone, 1865: 278 \\
\hline & & & & Sulcatimorda & Mequignon, 1946: 63 \\
\hline & & & & Variimorda & Mequignon, 1946: 62 \\
\hline & & & Mordellapygium & & $\begin{array}{l}\text { Ray, 1930a: } 143 \\
\text { Ermisch, 1950: } 56\end{array}$ \\
\hline & & & Mordellaria & & $\begin{array}{l}\text { Ermisch, 1950: } 69 \\
\text { Tokeji, 1954: } 4 \\
\text { Ermisch, 1956: } 303 \\
\text { Franciscolo, 1956: } 215 \\
\text { Horak, 1995:81 [South Africa] } \\
\text { Lu, 2009: } 118 \text { [Africa, America, Asia] }\end{array}$ \\
\hline & & & Mordellina & & $\begin{array}{l}\text { Schilsky, 1908 [5]: } 137 \\
\text { Franciscolo, 1962: } 107 \\
\text { Ermisch, 1965: } 199 \\
\text { Batten, 1990: } 150 \text { [Papua New } \\
\text { Guinea] } \\
\text { Franciscolo, 1990: } 211 \text { [Sierra Leone] }\end{array}$ \\
\hline & & & & Pseudomordellistena & Ermisch, 1958: 386 \\
\hline & & & Mordelloides & & $\begin{array}{l}\text { Ray, 1939 } \\
\text { Ray, 1941: } 277\end{array}$ \\
\hline & & & Mordellopalpus & & Franciscolo, 1955: 179 \\
\hline & & & Neocurtimorda & & $\begin{array}{l}\text { Franciscolo, 1949: } 1 \\
\text { (Doriana, 1949: 1-4) } \\
\text { Franciscolo, 1950 } \\
\text { Franciscolo, 1955: } 171 \\
\text { Franciscolo, 1990: } 207 \text { [Sierra Leone] }\end{array}$ \\
\hline & & & Neoglipa & & $\begin{array}{l}\text { Franciscolo, 1952 } \\
\text { Franciscolo, 1952a: } 332 \text { [New Guinea } \\
\text { Island] }\end{array}$ \\
\hline & & & & Macroglipa & $\begin{array}{l}\text { Franciscolo, 1952: } 332 \text { [New Guinea } \\
\text { Island] }\end{array}$ \\
\hline & & & Stenoglipa & & $\begin{array}{l}\text { Franciscolo, 1952: } 344 \text { [New Guinea } \\
\text { Island] }\end{array}$ \\
\hline & & & Neotomoxia & & Ermisch, 1950: 10 \\
\hline & & & Ophthalmoglipa & & $\begin{array}{l}\text { Franciscolo, 1952: } 353 \text { [New Guinea] } \\
\text { (Doriana, 1952: 2) } \\
\text { Franciscolo, 1955: } 1052 \\
\text { Franciscolo, 1959: } 23\end{array}$ \\
\hline & & & & Stenoglipa & Takakuwa \& Masatoshi, 2000: 64 \\
\hline & & & Paramordella & & Píc, 1936: 259 \\
\hline & & & Paramordellana & & $\begin{array}{l}\text { Ermisch, 1968: } 265 \\
\text { Ermisch, 1950: } 59\end{array}$ \\
\hline & & & Paramordellaria & & $\begin{array}{l}\text { Ermisch, } 1968 \\
\text { Lu \& Jackman \& Johnson, 1997: } 746\end{array}$ \\
\hline & & & Paraphungia & & Ermisch, 1969: 4 \\
\hline & & & Parastenomordella & & Ermisch, 1950: 60 [Brazil: Brasilien] \\
\hline & & & Paratomoxia & & $\begin{array}{l}\text { Ermisch, 1950: } 5 \\
\text { Tokeji, 1954: } 3\end{array}$ \\
\hline & & & & Metatomoxia & Chujo, 1957: 1 \\
\hline & & & Paratomoxioda & & Ermisch, 1954 \\
\hline & & & Phungia & & $\begin{array}{l}\text { Píc, 1922: 15, } 17 \\
\text { Ermisch, 1950: } 49\end{array}$ \\
\hline & & & Plesitomoxia & & $\begin{array}{l}\text { Ermisch, 1954: } 170 \\
\text { Ermisch, 1955 } \\
\text { Franciscolo, 1990: } 207 \text { [Sierra Leone] }\end{array}$ \\
\hline
\end{tabular}


Table A1. Cont.

\begin{tabular}{|c|c|c|c|c|c|}
\hline Family & Subfamily & Tribe & Genus & Sugenus & Citation \\
\hline & & & Praemordella & & Shchegoleva-Barovskaya, 1929: 27 \\
\hline & & & Pseudomordellaria & & Shchegoleva-Barovskaya, 1929: 27 \\
\hline & & & Pseudotomoxia & & Ermisch, 1950: 52 \\
\hline & & & Sphaeromorda & & Franciscolo, 1950 \\
\hline & & & Stenaliamorda & & Ermisch \& Chûjô, 1968 \\
\hline & & & Stenomorda & & Ermisch, 1950: 17 \\
\hline & & & Stenomordella & & $\begin{array}{l}\text { Ermisch, 1941: 115 } \\
\text { Ermisch, 1941: 115-117 } \\
\text { Ermisch, 1950: } 57\end{array}$ \\
\hline & & & Stenomordellaria & & $\begin{array}{l}\text { Ermisch, 1950: 57 } \\
\text { Ermisch, 1950: 34-92 } \\
\text { Franciscolo, 1981: } 205\end{array}$ \\
\hline & & & Stenomordellariodes & & Ermisch, 1954: 92 \\
\hline & & & Succimorda & & Kubisz \& Daniel, 2001: 273 \\
\hline & & & Tolidomordella & & $\begin{array}{l}\text { Ermisch, 1950: } 69 \\
\text { Lu, Wenhua \& Jackman \& Johnson, } \\
\text { 1997: } 752\end{array}$ \\
\hline & & & Tolidomoxia & & Ermisch, 1950: 13 \\
\hline & & & Tomoxia & & $\begin{array}{l}\text { Costa, 1854: } 8 \\
\text { Smith, 1882: } 78 \text { [America] } \\
\text { Costa, 1884: } 8 \\
\text { Champion, 1898: } 84 \\
\text { Nicolay, 1914: } 30 \\
\text { Chujo, 1935: } 78 \text { [China: Taiwan; } \\
\text { Japan; Philippines; Papua, Australia, } \\
\text { Europe, Mexico, Southern America] } \\
\text { Liljeblad, 1945: } 54 \text { [North America, } \\
\text { Europe] } \\
\text { Ray, 1949: } 285 \text { [Fiji] } \\
\text { Ermisch, 1950: } 52 \\
\text { Buck, 1954: 16 } \\
\text { Ermisch, 1956: } 298 \\
\text { Franciscolo, 1956: } 2 \\
\text { Downie, 1996: 1156 [North-Eastern } \\
\text { America, North-Eastern Mexico] } \\
\text { Lu \& Jackman \& Johnson, 1997: } 743 \\
\text { Takakuwa, 1999: } 1\end{array}$ \\
\hline & & & & Metatomoxia & Chujo, 1957: 1 \\
\hline & & & Tomoxioda & & Ermisch, 1950: 53 \\
\hline & & & Trichotomoxia & & $\begin{array}{l}\text { Franciscolo, 1950: } 130 \\
\text { Franciscolo, 1955: } 1052 \\
\text { Franciscolo, 1955: } 164\end{array}$ \\
\hline & & & Variimorda & & $\begin{array}{l}\text { Méquignon, } 1946 \\
\text { Ermisch, 1956:298 } \\
\text { Horak, 1985: } 4 \\
\text { Serrahima, 2007: } 560\end{array}$ \\
\hline & & & & Galeimorda & Horak, 1985: 15 \\
\hline & & & & Sulcatimorda & Batten, 1977: 167 \\
\hline & & & Variimorda & & $\begin{array}{l}\text { Mequignon, } 1946 \\
\text { Serrahima, 2007: } 560\end{array}$ \\
\hline & & & Wittmerimorda & & Franciscolo, 1952: 69 \\
\hline & & & Yakuhananomia & & $\begin{array}{l}\text { Kônô, 1935: } 124 \text { [Japan] } \\
\text { Fauna, 1936: } 25 \text { [Japan] } \\
\text { Ermisch, 1950: } 55 \\
\text { Lu, 1997: } 747\end{array}$ \\
\hline & & & Zeamordella & & $\begin{array}{l}\text { Broun, 1886: } 84 \\
\text { Ermisch, 1950: 70 } \\
\text { Franciscolo, 1981: } 191 \\
\text { Franciscolo, 1992: } 569\end{array}$ \\
\hline
\end{tabular}


Table A1. Cont.

\begin{tabular}{|c|c|c|c|c|c|}
\hline Family & Subfamily & Tribe & Genus & Sugenus & Citation \\
\hline & & \multirow{20}{*}{ Mordellistenini } & & & $\begin{array}{l}\text { Ermisch, 1941 } \\
\text { Franciscolo, 1955: } 1062 \\
\text { Franciscolo, 1956: } 3 \\
\text { Franciscolo, 1956: } 225 \\
\text { Franciscolo, 1959: } 23 \\
\text { Franciscolo, 1962: } 101 \\
\text { Nomura, 1967: 15 } \\
\text { Nomura, 1967: 15 } \\
\text { Serrahima, 2007: } 560 \\
\text { Horak, 2009: 209 }\end{array}$ \\
\hline & & & Asiatolida & & Shiyake, 2000: 26 \\
\hline & & & Calyce & & $\begin{array}{l}\text { Champion, 1891: } 307 \\
\text { Champion, 1898: } 92 \\
\text { Blair, 1922: } 221 \\
\text { Ray, 1941: 284 } \\
\text { Ermisch, 1943: 53-60 } \\
\text { Ermisch, 1950: } 87\end{array}$ \\
\hline & & & Calycemorda & & Ermisch, 1969: 304 \\
\hline & & & Calyceoidea & & Ermisch, 1969: 307 \\
\hline & & & Dellamora & & $\begin{array}{l}\text { Normand, 1916: } 284 \\
\text { Ermisch, 1941:711, 721, } 722 \\
\text { Van Zwaluwenburg, } 1948 \text { [Solomon } \\
\text { Islands] } \\
\text { Ray, 1949: } 304 \\
\text { Ermisch, 1950: } 80\end{array}$ \\
\hline & & & Diversimorda & & Ermisch, 1969: 301 \\
\hline & & & Ermischiella & & $\begin{array}{l}\text { Ermisch, 1941: } 724 \\
\text { Liljeblad, 1950 } \\
\text { Franciscolo, 1950: } 2 \\
\text { Franciscolo, 1950 }\end{array}$ \\
\hline & & & Fahraeusiella & & Ermisch, 1953: 316 \\
\hline & & & Falsomordellina & & Nomura, 1966: 44 \\
\hline & & & \multirow{4}{*}{ Falsomordellistena } & & $\begin{array}{l}\text { Ermisch, 1941: 715, } 725 \\
\text { Ermisch, 1950: } 83 \\
\text { Tokeji, 1954: } 14\end{array}$ \\
\hline & & & & Falsomordellistena & Lu, 2009: 119 \\
\hline & & & & Falsomordellistenoda & Ermisch, 1950a: 85 \\
\hline & & & & Palaeostena & Kubisz, 2003: 185 (Eocene Fossil) \\
\hline & & & Falsopseudomoxia & & Franciscolo, 1965 \\
\hline & & & Glipostena & & $\begin{array}{l}\text { Ermisch, 1941: 715, } 723 \\
\text { Ermisch, 1950: 80 } \\
\text { Tokeji, 1954: 19 } \\
\text { Franciscolo, 1962: } 118 \\
\text { Franciscolo, 1999: } 101 \\
\text { Franciscolo, 1999: } 242\end{array}$ \\
\hline & & & Glipostenoda & & $\begin{array}{l}\text { Ermisch, 1950: 81 } \\
\text { Ermisch, 1949-1950: 45, } 81 \\
\text { Krefeld, 1949-50, 45-46: } 80 \\
\text { Franciscolo, 1958: 71 } \\
\text { Franciscolo, 1962: 121 } \\
\text { Lu, 1997: 761 } \\
\text { Lu, 2009: } 121\end{array}$ \\
\hline & & & Gymnostena & & Franciscolo, 1950: 7 \\
\hline & & & \multirow[t]{2}{*}{ Mordellina } & & $\begin{array}{l}\text { Schilsky, 1908: 137 } \\
\text { Franciscolo, 1962: } 107 \\
\text { Ermisch, 1965: } 199 \\
\text { Batten, 1990: } 150 \text { [Papua New } \\
\text { Guinea] } \\
\text { Franciscolo, 1990: } 211 \text { [Sierra Leone] }\end{array}$ \\
\hline & & & & Mordellina & Ermisch, 1967: 133 \\
\hline
\end{tabular}


Table A1. Cont.

\begin{tabular}{|c|c|c|c|c|c|}
\hline \multirow[t]{2}{*}{ Family } & \multirow[t]{2}{*}{ Subfamily } & \multirow[t]{2}{*}{ Tribe } & \multirow[t]{3}{*}{ Genus } & \multicolumn{2}{|l|}{ Sugenus } \\
\hline & & & & Pseudomordellina & Nomura, 1966: 49 \\
\hline & & & & Pseudomordellistena & $\begin{array}{l}\text { Ermisch, 1952a: } 145 \\
\text { Ermisch, 1965: } 199 \\
\text { Batten, 1990: } 150 \text { [Papua New } \\
\text { Guinea] } \\
\text { Franciscolo, 1990: } 211 \text { [Sierra Leone] }\end{array}$ \\
\hline & & & Mordellistena & & $\begin{array}{l}\text { Linne, 1758: } 420 \\
\text { Costa, 1853 } \\
\text { Costa, 1854: 16, } 31 \\
\text { Helmuth, 1864: } 105 \text { [America: Illinois] } \\
\text { Broun, 1880: 415 } \\
\text { Costa., 1882: 85 [America: New York] } \\
\text { Smith, 1883: 80, 81 [America] } \\
\text { Champion, 1895: } 271 \text { [North- Western } \\
\text { Australia] } \\
\text { Champion, 1896: } 50 \\
\text { Kolbe, 1897: 254 } \\
\text { Champion, 1898: } 92 \\
\text { Webster, 1901: 176 } \\
\text { Dury Charles, 1906 [North America] } \\
\text { Nicolay, 1914: } 30 \\
\text { Champion, 1917: 181 } \\
\text { Kono, 1928: 37 [Japan] } \\
\text { Stshegoleva-Barovskaja, 1930: 57 } \\
\text { Scegoleva-Barovskaja, 1931: 419 } \\
\text { Ray, 1941: 286 [Mexico, Guatemala] } \\
\text { Ermisch, 1941: 711, 716 } \\
\text { Liljeblad, 1945: 68 } \\
\text { Breuning, 1948: 503-523 } \\
\text { Ray, 1949: 286 [Fiji] } \\
\text { Ermisch, 1950: 76 } \\
\text { Ermisch, 1950: } 52 \\
\text { Ermisch, 1950: } 31 \\
\text { Pic, 1950: 148 } \\
\text { Pic, 1952: 106 } \\
\text { Buck, 1954: 16 } \\
\text { Tokeji, 1954: } 5\end{array}$ \\
\hline & & & & & $\begin{array}{l}\text { Franciscolo, 1955: } 1062 \\
\text { Ermisch, 1956: 305 } \\
\text { Franciscolo, 1956: } 3 \\
\text { Franciscolo, 1956: } 232 \\
\text { Franciscolo, 1959: } 23 \\
\text { Franciscolo, 1962: } 101 \\
\text { Compte, 1969: 110 } \\
\text { Horak, 1980: 285 } \\
\text { Odnosum, 1989: } 333 \\
\text { Franciscolo, 1990: } 211 \text { [Sierra Leone] } \\
\text { Downie, 1996: 1159 [Northern } \\
\text { America, Northern Mexico] } \\
\text { Lu, 1997: 756 } \\
\text { Serrahima, 2007: } 560\end{array}$ \\
\hline & & & & Mordella & Blair, 1921: 281 \\
\hline & & & & Mordellikoiles & Franciscolo, 1942:133 \\
\hline & & & & Mordellina & $\begin{array}{l}\text { Schilsky, 1908: } 137 \\
\text { Ermisch, 1950: } 50\end{array}$ \\
\hline & & & & Mordellistena & $\begin{array}{l}\text { Costa, 1854 } \\
\text { Emery, 1876: } 81 \\
\text { Chujo, 1935: } 80 \\
\text { Franciscolo, 1955: } 1062 \\
\text { Ermisch, 1956: 305 } \\
\text { Franciscolo, 1956: } 232 \\
\text { Ermisch, 1963: 55 } \\
\text { Serrahima, 2007: } 560 \\
\text { Lu, 2009: 122 }\end{array}$ \\
\hline & & & & Mordellistenula & Stshegoleva-Barovskaja, 1930: 56 \\
\hline
\end{tabular}


Table A1. Cont.

\begin{tabular}{|c|c|c|c|c|c|}
\hline Family & Subfamily & Tribe & Genus & Sugenus & Citation \\
\hline & & & & Mordellochroa & $\begin{array}{l}\text { Emery, 1876: } 80 \\
\text { Champion, 1898: } 92\end{array}$ \\
\hline & & & & Pseudomordellina & $\begin{array}{l}\text { Ermisch, 1952: } 47 \\
\text { Franciscolo, 1955: } 1076 \\
\text { Ermisch, 1956: } 311 \\
\text { Franciscolo, 1956: } 240 \\
\text { Franciscolo, 1959: } 27\end{array}$ \\
\hline & & & & Pseudomordellistena & $\begin{array}{l}\text { Ermisch, 1951(1952): 143, } 145 \\
\text { Nakane, 1957: } 54 \\
\text { Nomura \& Kato, 1957: } 81\end{array}$ \\
\hline & & & Mordellistenalia & & Ermisch, 1958: 376 [Congo] \\
\hline & & & Mordellistenochroa & & Horák, 1982 \\
\hline & & & Mordellistenoda & & $\begin{array}{l}\text { Ermisch, 1941: } 589 \\
\text { Ermisch, 1941: 715, } 722 \\
\text { Ermisch, 1950: } 87\end{array}$ \\
\hline & & & Mordellistenula & & $\begin{array}{l}\text { Stchegoleva-Barowskaja, } 1930 \\
\text { Stshcgolewa-Barowskaja, 1931: } 57 \\
\text { Ermisch, 1941: 711, 718, } 719 \\
\text { Ermisch, 1950: 76 } \\
\text { Ermisch, 1956: } 305 \\
\text { Compte, 1969: } 114\end{array}$ \\
\hline & & & Mordellochroa & & $\begin{array}{l}\text { Emery, 1876: 80 } \\
\text { Ermisch, 1941: 714, } 717 \\
\text { Franciscolo, 1950: } 6 \\
\text { Ermisch, 1950: 78-79 } \\
\text { Tokeji, 1954: 12 } \\
\text { Ermisch, 1956: } 312 \\
\text { Kazab, 1979: 83 } \\
\text { Odnosum, 1996: } 47\end{array}$ \\
\hline & & & Mordellochroidea & & Ermisch, 1969: 311 \\
\hline & & & Mordelloxena & & Franciscolo, 1950b: 6 \\
\hline & & & Morphomordellochroa & & $\begin{array}{l}\text { Emery, } 1876 \\
\text { Ermisch, 1969: } 308 \\
\text { Serrahima, 2007: } 560\end{array}$ \\
\hline & & & Neomordellisteng & & Ermisch, 1950: 52 \\
\hline & & & 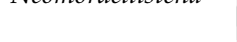 & Neomordellistena & Batten, 1981: 348 \\
\hline & & & Palmorda & & Ermisch, 1969: 312 \\
\hline & & & Palpomorda & & Ermisch, 1969 \\
\hline & & & Paramordellistena & & Ermisch, 1950: 73 \\
\hline & & & Phunginus & & Píc, 1922 \\
\hline & & & Pselaphokentron & & Franciscolo, 1955: 184 \\
\hline & & & Pseudodellamora & & $\begin{array}{l}\text { Ermisch, 1941: 714, } 720 \\
\text { Ermisch, 1942 } \\
\text { Ermisch, 1950: } 80\end{array}$ \\
\hline & & & Pseudotolida & & Ermisch, 1950: 86 \\
\hline & & & Raymordella & & Franciscolo, 1956: 227 \\
\hline & & & Rolcikomorda & & Horak, 2008: 67-68 [Madagascar] \\
\hline & & & & Hauckina & Horak, 2008: 72 [Madagascar] \\
\hline & & & Tolida & & $\begin{array}{l}\text { Mulsant, } 1856 \\
\text { Ermisch, 1941 } \\
\text { Franciscolo, 1942: } 8 \\
\text { Ermisch, 1956: } 312\end{array}$ \\
\hline & & & Tolidopalpus & & $\begin{array}{l}\text { Ermisch, } 1951 \\
\text { Ermisch, 1952: 144, } 149 \\
\text { Shiyake \& Shigehiko, 1995: } 12\end{array}$ \\
\hline & & & Tolidostena & & $\begin{array}{l}\text { Ermisch, 1942: } 674 \\
\text { Ermisch, 1950: } 79 \\
\text { Kiyoyama \& Yoshimi, 1991: } 53\end{array}$ \\
\hline
\end{tabular}


Table A1. Cont.

\begin{tabular}{|c|c|c|c|c|c|}
\hline \multirow[t]{12}{*}{ Family } & \multirow{5}{*}{\multicolumn{2}{|c|}{ Subfamily }} & \multirow[t]{3}{*}{ Genus } & Sugenus & Citation \\
\hline & & & & Neotolidostena & Kiyoyama \& Yoshimi, 1991: 53 \\
\hline & & & & Tolidostena & Kiyoyama \& Yoshimi 1991: 54 \\
\hline & & & Uhligia & & Horák, 1990: 141 \\
\hline & & & Xanthomorda & & $\begin{array}{l}\text { Ermisch, } 1968 \\
\text { Ermisch, 1969 } \\
\text { Batten, 1990: } 143 \text { [Papua New } \\
\text { Guinea] }\end{array}$ \\
\hline & & & & & Franciscolo, 1957: 237 \\
\hline & & Reynoldsiellini & Reynoldsiella & & $\begin{array}{l}\text { Ray, 1930: } 164 \\
\text { Ermisch, 1950: } 48\end{array}$ \\
\hline & & & & & $\begin{array}{l}\text { Franciscolo, 1955: } 1056 \\
\text { Franciscolo, 1956: } 219\end{array}$ \\
\hline & & & Brodskyella & & Horák, 1989: 37 \\
\hline & & & Pselaphostena & & $\begin{array}{l}\text { Franciscolo, 1950: } 130 \\
\text { Franciscolo, 1952: } 456\end{array}$ \\
\hline & & Stenaliini & Stenalia & & $\begin{array}{l}\text { Mulsant, 1856: 83, } 387 \\
\text { Champion, 1898: } 92 \\
\text { Ermisch, 1950: 76 } \\
\text { Franciscolo, 1955: } 1056 \\
\text { Ermisch, 1956: 305 } \\
\text { Franciscolo, 1956: } 220 \\
\text { Horak, 1978: } 402 \\
\text { Horak, 1995: } 89\end{array}$ \\
\hline & & & Stenaliodes & & Franciscolo, 1956: 219 \\
\hline
\end{tabular}

\section{References}

1. Liljeblad, E. Monograph of the Family Mordellidae (Coleoptera) of North America, North of Mexico; University of Michigan Press: Ann Arbor, MI, USA, 1945; 229p.

2. Liu, Y.; Xue, H.; Yang, X. Advances in systematics of Chinese Mordellidae (Coleoptera). J. Environ. Entomol. 2015, 37, 865-870, (In Chinese with English abstract).

3. Uhler, L.D. Mortality of the goldenrod gall fly, Eurosta solidaginis in the vicinity of Ithaca, New York. Ecology 1961, 42, 215-216. [CrossRef]

4. Tamutis, V.; Tamute, B.; Ferenca, R. A catalogue of Lithuanian beetles (Insecta, Coleoptera). ZooKeys 2011, 121, 1-494. [CrossRef] [PubMed]

5. Batelka, J.; Kundrata, R.; Bocak, L. Position and relationships of Ripiphoridae (Coleoptera: Tenebrionoidea) Inferred from Ribosomal and Mitochondrial Molecular Markers. Ann. Zool. 2016, 66, 113-123. [CrossRef]

6. Falin, Z.H. 102. Ripiphoridae Gemminger and Harold 1870 (1853). In American Beetles; CRC Press LLC: Boca Raton, FL, USA, 2002; Volume 2, pp. 431-444.

7. Gunter, N.L.; Levkaničová, Z.; Weir, T.H.; Ślipiński, A.; Cameron, S.L.; Bocak, L. Towards a phylogeny of the Tenebrionoidea (Coleoptera). Mol. Phylogenet. Evol. 2014, 79, 305-312. [CrossRef] [PubMed]

8. Dietrich, C.H. Overview of the phylogeny, taxonomy and diversity of the leafhopper (Hemiptera: Auchenorrhyncha: Cicadomorpha: Membracoidea: Cicadellidae) vectors of plant pathogens. In Proceedings of the 2013 International Symposium on Insect Vectors and Insect-Borne Diseases, Taichung, Taiwan, August 2013; pp. 47-70.

9. Horak, J. Order Coleoptera, family Mordellidae. In Arthropod Fauna of the UAE; van Harten, A., Ed.; Dar Al Ummah Printing, Publishing, Distribution \& Advertising, Dar Al Ummah Printing: Abu Dhabi, UAE, 2009; Volume 2, pp. 207-215.

10. Khalaf, K.T. Wing venation and phylogenetic relationshipsin Mordellidae (Coleoptera: Heteromera). Fla. Entomol. 1970, 53, 153-160. [CrossRef]

11. Odnosum, V.K. Wing structure in beetles of subfamily Anaspidinae (Coleoptera, Mordellidae). Vestn. Zool. 1989, 69-71.

12. Lu, W.; Jackman, J.A.; Johnson, P.W. Male genitalia and phylogenetic relationships in North American Mordellidae (Coleoptera). Ann. Entomol. Soc. Am. 1997, 90, 742-767. [CrossRef] 
13. Odnosum, V.K. Tumbling flower beetles (Coleoptera: Mordellidae) of the Central and Eastern Europe fauna. Communication 2. Subfamily Mordellinae. Tribe Mordellistenini. Kharkovskogo Entomol. Obshchestva Izv. 2005, 12, 93-112.

14. Odnosum, V.K. Mordellistena dolini sp. n., a new mordellid beetle of the gemellata group (Coleoptera, Mordellidae). Vestn. Zool. 2005, 39, 53-54, 103.

15. Odnosum, V.K. Mordellid beetles of the Mordellistena parvula group (Coleoptera, Mordellidae) in the fauna of Ukraine. Vestn. Zool. 2006, 40, 311-319.

16. Odnosum, V.K. Larvae of the mordellid beetle Mordellistena kraatzi (Coleoptera, Mordellidae). Vestn. Zool. 2007, 41, 85-86, 96.

17. Odnosum, V.K. The first record of the genus Pseudotolida (Coleoptera, Mordellidae) from Vietnam and Far East Russia. Vestn. Zool. 2008, 42, 359-362.

18. Odnosum, V.K. Larval morphology of Mordellistina falsoparvula. Vestn. Zool. 1983, 82-84.

19. Odnosum, V.K.; Mamayev, B.M. New data on morphology and systematics of xylophylic mordelid beetle larvae (Coleoptera, Mordelidae) of Euro-Caucasian faunistic complex. Vestn. Zool. 1986, 1986, 18-24.

20. Hayashi, N. Illustrations for identification of larvae of the Cucujoidea (Coleoptera) found living in dead trees in Japan. Mem. Educ. Inst. Priv. Sch. Jpn. 1980, 72, 95-147.

21. Mamayev, B.M.; Odnosum, V.K. New data on morphology and systematics of the Mordellidae larvae (Coleoptera) of the Far Eastern USSR fauna. Vestn. Zool. 1984, 1984, 61-66.

22. Ford, E.J.; Jackman, J.A. New larval host plant associations of tumbling flower beetles (Coleoptera: Mordellidae) in North America. Coleopt. Bull. 1996, 50, 361-368.

23. Zemoglyadchuk, A.V. Morphological character of larvae of three species of mordelling beetles Mordellistena parvula groups (Coleoptera, Mordellidae). Vyestsi Natsyyanal'nai Akademii Navuk Byelarusi Syeryya Biyalahichnykh Navuk 2008, 1, 118-122.

24. Fan, X. A new species and a new record species of genus Mordellistena (Coleoptera: Mordellidae). Entomotaxonomia 1995, 17, 23-25.

25. Qureshi, J.A.; Stahlman, P.W.; Michaud, J.P. Plant population and weeds influence stalk insects, soil moisture, and yield in rainfed sunflowers. Insect Sci. 2007, 14, 425-435. [CrossRef]

26. Huang, D.-Y.; Yang, J. Early Cretaceous fossil Mordellidae (Insecta, Coleoptera) from western Beijing. Acta Palaeontol. Sin. 1999, 38, 125-132.

27. Scegoleva-Barovskaja, T. Der erste Vertreter der Familie Mordellidae (Coleoptera) aus den Juraformation Turkestans. C. R. Acad. Sci. URSS 1929, 25-29.

28. Medvedev, L.N. New Mesozoic Coleoptera (Cucujoidea) of Asia. Paleontol. J. 1969, 119-125.

29. Wang, W. On Liaoximordellidae fam. nov. (Coleoptera, Insecta) from the Jurassic of western Liaoning Province, China. Dizhi Xuebao 1993, 67, 86-94.

30. Jell, P.A.; Duncan, P.M. Invertebrates, mainly insects, from the freshwater, Lower Cretaceous, Koonwarra fossil bed, (Korumburra Group), South Gippsland, Victoria. In Plants and Invertebrates from the Lower Cretaceous Koonwarra Fossil Bed, South Gippsland, Victoria. Memoirs of the Association of the Australasian Palaeontologists; Jell, P.W., Roberts, J., Eds.; Association of Australasian Palaeontologists: Sydney, Australia, 1986; Volume 3.

31. Cockerell, T.D.A. Fossil insects in the United States National Museum. Proc. United States Natl. Mus. 1925, 64, 1-15. [CrossRef]

32. Statz, G. Fossile Mordellidae und Lamellicornia (Coleoptera) aus den Oberoligozan von Rott. Palaeontogr. Abt. A 1952, 102, 1-17.

33. Nel, A. Sur la presence d'un coleoptere Mordellidae fossile dans les calcaires stampiens de Cereste (Alpes de Haute-Provence). Entomologiste 1985, 41, 119-121.

34. Kubisz, D. A new fossil species from the genus Falsomordellistena Ermisch, 1941 (Coleoptera, Mordellidae) with description of a new subgenus. Acta Zool. 2003, 46, 185-188.

35. Liu, M.; Lu, W.; Ren, D. A new fossil mordellid (Coleoptera: Tenebrionoidea: Mordellidae) from the Yixian Formation of western Liaoning Province, China. Zootaxa 2007, 1415, 49-56.

36. Liu, M.; Zhao, Y.-Y.; Ren, D. Discovery of three new mordellids (Coleoptera, Tenebrionoidea) from the Yixian Formation of western Liaoning, China. Cretac. Res. 2008, 29, 445-450. [CrossRef]

37. Peris, D.; Ruzzier, E. A new tribe, new genus, and new species of Mordellidae (Coleoptera: Tenebrionoidea) from the Early Cretaceous amber of Spain. Cretac. Res. 2013, 45, 1-6. [CrossRef] 
38. Odnosum, V.K. About the stady of fossil mordellid and scraptiid-beetle (Coleoptera: Mordellidae, Scraptiidae) of the Old Word. Український ентомологічний журнал 2013, 43-49.

39. Liu, Y.; Dietrich, C.H.; Braxton, S.M.; Wang, Y.; Zhang, Y.; He, H. Publishing trends and productivity in insect taxonomy from 1950 to 2012 based on analysis of the Zoological Record for four families: Cicadellidae, Miridae, Pyralidae and Staphylinidae. PeerJ 2018. sent for submission.

40. Joppa, L.N.; Roberts, D.L.; Pimm, S.L. Taxonomy that matters: Response to Bacher. Trends Ecol. Evol. 2012, 27, 66. [CrossRef]

41. Bacher, S. Still not enough taxonomists: Reply to Joppa et al. Trends Ecol. Evol. 2012, 27, 65-66. [CrossRef] [PubMed]

42. Paknia, O.; Rajaei Sh., H.; Koch, A. Lack of well-maintained natural history collections and taxonomists in megadiverse developing countries hampers global biodiversity exploration. Org. Divers. Evol. 2015, 15, 619-629. [CrossRef]

43. Pearson, D.L.; Hamilton, A.L.; Erwin, T.L. Recovery plan for the endangered taxonomy profession. Bioscience 2011, 61, 58-63. [CrossRef]

44. Godfray, H.C.J. Challenges for taxonomy. Nature 2002, 417, 17. [CrossRef] [PubMed]

(C) 2018 by the authors. Licensee MDPI, Basel, Switzerland. This article is an open access article distributed under the terms and conditions of the Creative Commons Attribution (CC BY) license (http:/ / creativecommons.org/licenses/by/4.0/). 